\title{
Complement Receptor Expression on Neutrophils at an Inflammatory Site, the Pseudomonas-infected Lung in Cystic Fibrosis
}

\author{
Melvin Berger, Ricardo U. Sorensen, Michael F. Tosi, Dorr G. Dearborn, and Gerd Döring* \\ Department of Pediatrics, Case Western Reserve University School of Medicine, Cleveland, Ohio 44106; and \\ *Eberhard-Karls-Universität Tübingen, Hygiene-Institut, Tübingen, Federal Republic of Germany
}

\section{Abstract}

Activation of human neutrophils (PMN) is accompanied by rapid upregulation of $\mathrm{CR1}$, the $\mathrm{C} 3 \mathrm{~b}$ receptor, and $\mathrm{CR3}$, the iC3b receptor, which also serves as the PMN's major adherence protein. This is necessary for migration and phagocytosis, but the extent of expression of these proteins on PMN at inflammatory sites has not been determined. We used monoclonal antibodies and flow cytometry to assess CR1 and CR3 expression on PMN in bronchoalveolar lavage (BAL) fluid of cystic fibrosis (CF) patients chronically infected with pseudomonas and in sterile joint fluid of arthritis patients. Resting peripheral blood PMN from these patients and normals expressed similar low levels of CR1 and CR3, and the patients' PMN increased CR1 and CR3 expression normally when stimulated in vitro. CR3 expression on CF BAL PMN was $90 \pm 12 \%$ of that on the same patient's blood cells stimulated in vitro with FMLP. In contrast, CR1 expression on BAL PMN was only $27 \pm 8 \%$ of that on stimulated blood cells. Similar results were obtained for joint PMN. This pattern could be reproduced in vitro by treating FMLP-stimulated blood cells with BAL supernatants or with pseudomonas or PMN elastase. The serine protease inhibitors, PMSF and $\alpha_{1}$-antitrypsin prevented the lavage supernatant from reducing CR1 expression, while metalloprotease inhibitors had no effect. Treatment of PMN with elastase in vitro decreased their ability to kill opsonized Pseudomonas aeruginosa.

These results suggest that PMN at inflammatory sites have maximally upregulated expression of their complement receptors, but that $\mathrm{CR1}$ is then cleaved by proteolysis in situ. Although not related to the basic defect in CF, this may interfere with efficient phagocytosis and contribute to the CF patient's inability to eradicate chronic lung infection.

\section{Introduction}

Circulating human neutrophils (PMN) bear on their surface relatively few $\mathrm{C} 3 \mathrm{~b}$ receptors $(\mathrm{CR} 1)^{1}$ and only small amounts of their major cell adherence protein, which also serves as the

Address reprint requests to Dr. Berger, Rainbow Babies' and Children's Hospital, 2101 Adelbert Road, Cleveland, OH 44106.

Received for publication 14 October 1987 and in revised form 18 April 1989.

1. Abbreviations used in this paper: $\mathrm{BAL}$, bronchoalveolar lavage; $\mathrm{C} 3 \mathrm{~b}$ and $\mathrm{iC} 3 \mathrm{~b}$, cleavage products of the third component of complement; $\mathrm{CR} 1, \mathrm{C} 3 \mathrm{~b} / \mathrm{C} 4 \mathrm{~b}$ receptor; $\mathrm{CR} 3$, iC3b receptor; CF, cystic fibrosis; $\mathrm{ZAS}$, zymosan activated serum.

J. Clin. Invest.

(c) The American Society for Clinical Investigation, Inc.

$0021-9738 / 89 / 10 / 1302 / 12 \$ 2.00$

Volume 84, October 1989, 1302-1313
iC3b receptor (CR3) (1-3). When PMN are activated by chemoattractants in vitro, the expression of these two molecules increases rapidly by a mechanism involving translocation of presynthesized receptors from intracellular pools to the cell surface (1-5). This is believed to be important in allowing the PMN to adhere to the endothelium and follow chemotactic gradients into the tissues, and also in facilitating phagocytosis of complement-coated microorganisms. Patients whose PMN are deficient in CR3 also have deficient expression of other members of this family of adherence proteins on their lymphocytes and monocytes, but their major clinical problems are due to recurrent infections and other manifestations suggestive of decreased penetration of PMN into the tissues (6). This may occur even though their circulating PMN counts are markedly elevated (6). Previous studies have shown that PMN in the circulation may have increased expression of $\mathrm{CR} 1$ and $\mathrm{CR} 3$ after intravascular or extracorporeal exposure to complement activation fragments such as C5a des-Arg (7-9). Increased CR3 expression on PMN in experimentally induced sterile exudates has also been documented $(10,11)$. However, no data are presently available on the extent of upregulation of these receptors on neutrophils that have migrated from the circulation into naturally occurring inflammatory exudates.

We report here observations on the expression of CR 1 and CR3 on inflammatory PMN obtained from an infected site, the pseudomonas-infected lung in cystic fibrosis (CF), as well as from sterile sites, joints involved in juvenile chronic arthritis. The results indicate that PMN from both types of inflammatory sites are similar, and have upregulated CR3 expression to nearly the same level achieved in vitro with the synthetic chemoattractant, FMLP. In contrast, the level of CR1 expression is much closer to the level on unstimulated resting blood cells. This discrepancy in the level of expression of the two receptors in vivo is markedly different from the proportionality of their expression observed under a wide variety of conditions in vitro. We also found comparable differences in CR 1 vs. CR3 expression on PMN obtained from the lungs of a patient with chronic pseudomonas pulmonary infection unrelated to CF. This and other data suggest that the relative deficiency in CR1 expression is not related to the underlying defect in CF. A pattern of receptor expression similar to that observed on inflammatory PMN could be reproduced in vitro by treating FMLP-stimulated isolated peripheral blood cells with a variety of proteases including pseudomonas and neutrophil elastases and with bronchoalveolar lavage supernatants from CF patients. This decrease in CR 1 expression was blocked by preincubating the lavage fluid with PMSF and $\alpha_{1}$ antitrypsin, which inhibit serine proteases, suggesting that PMN elastase was responsible. Treatment of isolated PMN with elastase impaired their ability to kill opsonized $P$. aeruginosa.

Our results thus demonstrate that complement receptor upregulation does occur on PMN in inflammatory exudates, 
but suggest that the expression of CR 1 may in turn be reduced due to cleavage by active proteases present in such exudates. Although not related to the underlying cellular defect in $\mathrm{CF}$, this decrease in CR1 expression seems likely to interfere with efficient complement-mediated phagocytosis. This may contribute to the inability of $\mathrm{CF}$ patients to clear the chronic pseudomonas infections that have become the major causes of morbidity and mortality in this disease.

\section{Methods}

Patients. The primary study population included seven CF patients with chronic pseudomonas lung infection, one child with chronic pseudomonas pulmonary infection unrelated to $C F$ and four others with juvenile chronic arthritis. The CF patients had mild to severe disease, as defined by the activity and physical examination criteria of the scoring system of Schwachman and Kulczycki (12). They were selected for this study when, in the opinion of their primary physician, bronchoscopy was indicated for diagnostic or therapeutic purposes, or when their condition permitted elective lavage for research purposes. Ten bronchoalveolar lavages were performed on these seven patients. The characteristics of the patients at the time of lavage are given in Table I. All were receiving parenteral antibiotics, generally ceftazadime and tobramycin, as well as vitamins and pancreatic enzyme replacement. Five lavages were performed on patients receiving corticosteroids and two were performed on a patient taking a nonsteroidal antiinflammatory agent (Feldene, Pfizer, Inc., New York). Five additional CF patients, clinically similar to those described in Table I were also lavaged for studies of the viability and oxidative metabolism of the lavage cells.

Non-CF patients included a 10-mo-old with hypotonia who had a tracheostomy and was chronically infected with $P$. aeruginosa, and four other patients, ages 5 to $20 \mathrm{yr}$, with chronic arthritis who underwent diagnostic arthrocentesis and whose joint fluid aspirates were sterile. Heparinized peripheral blood samples of 12-24 ml were obtained from all patients and controls just before their inflammatory fluids were sampled. In addition, control peripheral blood samples were obtained from healthy adult volunteers. Six healthy young adult volunteers also underwent bronchoalveolar lavage. All subjects gave informed consent and all protocols were approved by the Institutional Review Board of University Hospitals of Cleveland.

Bronchoalveolar lavage. Subsegmental lavage was performed using a pediatric flexible fiberoptic bronchoscope on awake patients, al- though some were lightly sedated with small doses of Valium (Roche Products, Inc., Manati, PR). Local anesthesia was achieved with topical lidocaine and/or cocaine. Multiple aliquots of 30-50 ml of warmed saline were instilled through the bronchoscope. In most cases the total amount of saline instilled did not exceed $200 \mathrm{ml}$ and the amount recovered was $50-75 \%$ of that instilled. Lavage fluid was immediately filtered through surgical gauze to remove mucus plugs and debris. All subsequent steps were performed at $0-4^{\circ} \mathrm{C}$. Lavage cells were harvested by centrifugation at $200 \mathrm{~g}$ for $10 \mathrm{~min}$ and washed three times in HBSS without $\mathrm{Ca}^{2+}$ or $\mathrm{Mg}^{2+}$ supplemented with $0.1 \% \mathrm{BSA}, 0.01 \%$ $\mathrm{NaN}_{3}$ and $10^{-4} \mathrm{M}$ PMSF (HBSS ${ }^{+}$); they were then held on ice in this solution. The initial lavage supernatant was centrifuged at $1,000 \mathrm{~g}$ for $15 \mathrm{~min}$, then aliquoted and stored at $-80^{\circ} \mathrm{C}$. Cells from arthrocentesis were handled the same way as lavage cells. Cell counts were performed using a hemocytometer and differential counts were done on Wright's stained cytocentrifuge preparations. Viability of lavage PMN and their capability to produce an oxidative metabolic burst in response to stimulation were assessed by flow cytometry, as described below.

Isolation of peripheral blood neutrophils. PMN were prepared from heparinized peripheral blood samples as previously described, using Percoll density gradients followed by hypotonic lysis of contaminating erythrocytes $(3,13)$. Purity and viability of these preparations exceeded 95\%. PMN were resuspended in $\mathrm{HBSS}$ without $\mathrm{Ca}^{2+}$ or $\mathrm{Mg}^{2+}$, which was supplemented with $0.1 \%$ gelatin (HBSS-gel). Cells were stimulated by incubation with the synthetic chemoattractant FMLP at $10^{-8} \mathrm{M}$ for $1 \mathrm{~h}$ at $37^{\circ} \mathrm{C}$ with intermittent vortexing. In some experiments, lavage or other inflammatory fluid cells were incubated in parallel with the same patient's peripheral blood cells under exactly the same conditions.

Immunofluorescent assessment of complement receptor expression and flow cytometry. After stimulation, aliquots of $10^{6}$ cells each that had been incubated at $37^{\circ} \mathrm{C}$ with FMLP or that had been held on ice were washed with $\mathrm{HBSS}^{+}$, and then reacted with monoclonal antibody to the ligand binding site of CR 1 (CD 35, produced by clone 3D9 from Dr. John O'Shea, National Institutes of Health, Bethesda, MD) or to the Mac 1 epitope of CR3 (CD 11b, produced by clone M1/70, obtained from the American Type Culture Collection, Rockville, MD) exactly as previously described (3). Cells were washed and then stained with fluorescein isothiocyanate-conjugated (FITC) $F\left(a^{\prime}\right)_{2}$ fragments of goat anti-mouse or anti-rat immunoglobulin (Cappel Laboratories, Cochranville, PA) and held on ice until examination in the flow cytometer, generally within $1 \mathrm{~h}$. Equivalent aliquots of cells were also reacted with the directly FITC-conjugated monoclonal antibodies:

Table I. Characteristics of Cystic Fibrosis Patients at the Time of Lavage

\begin{tabular}{|c|c|c|c|c|c|c|}
\hline Patient no. & $\begin{array}{l}\text { Age of time } \\
\text { of lavage }\end{array}$ & $\begin{array}{l}\text { Clinical } \\
\text { condition* }\end{array}$ & Antiinflammatory treatment & Culture results & $\begin{array}{l}\text { Cell no. } \\
\text { recovered }\end{array}$ & $\begin{array}{l}\text { \%PMN } \\
\text { in lavage }\end{array}$ \\
\hline & $y r$ & & & & in millions & \\
\hline \multirow[t]{2}{*}{1} & 24.5 & Moderate & Feldene $2 \mathrm{mg}$ QD & P.a. ${ }^{\ddagger}$, P.c. & 22 & 98 \\
\hline & 26 & Severe & $\begin{array}{l}\text { Prednisone } 50 / 20 \mathrm{mg} \text { QOD } \\
\text { + Feldene } 2 \mathrm{mg} \text { QD }\end{array}$ & P.a., P.c. & 147 & 98 \\
\hline \multirow[t]{2}{*}{2} & 24 & Severe & Medrol $32 \mathrm{mg}$ QOD & P.c., Candida & 270 & 98 \\
\hline & 24.5 & Severe & Medrol $32 \mathrm{mg}$ QOD & P.c. & 44 & 98 \\
\hline 3 & 21.5 & Severe & None & $\begin{array}{l}\text { Aspergillus } \\
\text { P.a., Candida }\end{array}$ & 200 & 98 \\
\hline \multirow[t]{2}{*}{4} & 23 & Moderate & None & P.c. & 37 & 98 \\
\hline & 24 & Moderate & Prednisone $5 / 20 \mathrm{mg}$ QOD & P.c. & 29 & 95 \\
\hline 5 & 21 & Moderate & Prednisone $40 \mathrm{mg}$ QOD & P.a., P.c. & 163 & 98 \\
\hline 6 & 21 & Mild & None & P.a. & 230 & 75 \\
\hline 7 & 23 & Mild & None & P.c. & 34 & 64 \\
\hline
\end{tabular}

* Based on activity and physical exam aspects of Schwachman-Kulczycki score. $\quad$ ‡ P.a., Pseudomonas aeruginosa. P.c., Pseudomonas cepacia. 
anti-HLA DR, which is expressed on mononuclear phagocytes and lymphocytes, but not on granulocytes (14); anti-Leu 11a (CD 16), an Fc receptor which is expressed on neutrophils and a small subpopulation of lymphocytes, but not on mononuclear phagocytes (15); or with directly conjugated isotype matched nonimmune control antibodies; all obtained from Becton-Dickinson Inc., Mountain View, CA.

Flow cytometry was performed with a Becton-Dickinson FACSAnalyzer equipped for measurement of green fluorescence (FLl, 515-545 nM), red fluorescence (FL2, 580-620 nM), light scatter at $90^{\circ}$, and cell volume by electrolyte displacement; as well as with a Consort 30 computer. Analysis gates were set using volume and $90^{\circ}$ scattered light to include both resting and FMLP-stimulated peripheral blood PMN. These gates were then used to selectively analyze 10,000 cells from each sample. Arithmetic mean fluorescence of each sample was automatically determined by the Consort 30 computer. For assessment of relative complement receptor expression, background fluorescence was determined on samples stained with the FITC-conjugated second antibodies but without the initial monoclonal antibodies, as previously described (3). For the directly conjugated antibodies, the background determined with directly conjugated isotype matched nonimmune control antibodies was used to set a discriminator and the fraction of cells in a given sample with fluorescence greater than background were expressed as the percent positive.

The level of significance of the differences between the means of fluorescence values or ratios of different samples was determined with Student's $t$ test.

Determination of viability and oxidative respiratory burst activity of lavage PMN. Since not all cells in the lavage fluid were included in the gates of the flow cytometer, which were set to include neutrophils only, we employed fluorescent methods to selectively determine the viability only of those cells falling within the gates and therefore also being analyzed for receptor expression. As the major indicator of viability, membrane integrity was assessed using fluorescein diacetate and propidium iodide (16). The former is retained and hydrolyzed by cells with intact membranes, yielding green fluorescence; while the latter is excluded from intact cells but binds to nucleic acids of cells with increased membrane permeability, giving red fluorescence. Isolated blood PMN and lavage cells, both at $10^{6} / \mathrm{ml}$, were incubated for $15 \mathrm{~min}$ at $37^{\circ} \mathrm{C}$ in HBSS containing $0.1 \%$ gelatin, $5 \times 10^{-3} \mathrm{M}$ EDTA and $10^{-4}$ M PMSF, with either $10^{-5} \mathrm{M}$ fluorescein diacetate or $4 \times 10^{-6} \mathrm{M}$ propidium iodide (both from Sigma Chemical Co., St. Louis, MO). 10,000 cells from each sample were analyzed in the flow cytometer. Discriminators were set based on the symmetric populations of the isolated blood neutrophils, which were $>98 \%$ positive for green fluorescence with fluorescein diacetate and $<2 \%$ positive for red fluorescence with propidium iodide, as determined by comparison with similar neutrophil preparations that had been permeabilized with $0.01 \%$ Triton X-100. Results for lavage neutrophils were expressed as the percentage falling within the discriminators set for intact isolated neutrophils.

To determine the functional capabilities of these cells, we again chose a fluorescence assay so that lavage cells falling within the gates of the flow cytometer could be selectively analyzed. This was done by measuring the oxidation of the nonfluorescent compound, dichlorofluorescin to the highly fluorescent dichlorofluorescein in response to stimulation with phorbol myristate acetate (PMA) as described by Bass et al. (17). Lavage cells at $10^{6} / \mathrm{ml}$ were incubated for $15 \mathrm{~min}$ at $37^{\circ} \mathrm{C}$ with $5 \times 10^{-6} \mathrm{M}$ dichlorofluorescin-diacetate in HBSS containing $0.1 \%$ gelatin, $10^{-4} \mathrm{M}$ PMSF, and $5 \times 10^{-3} \mathrm{M}$ EDTA. To one of two equivalent aliquots of cells, PMA was added from a stock solution in DMSO to give a final concentration of $100 \mathrm{ng} / \mathrm{ml}$ and incubation was continued at $37^{\circ} \mathrm{C}$. Fluorescence of 10,000 cells from each sample was recorded just before addition of the phorbol ester and 15-30 min later. Results were expressed as the percent of cells shifting to higher fluorescence in the presence of PMA as compared to the unstimulated control.

In vitro experiments with isolated normal PMN. To determine the proportionality of $\mathrm{CR} 1$ and $C R 3$ expression under a variety of condi- tions, PMN isolated from peripheral blood of normal donors were incubated as described above for FMLP, but the indicated concentrations of the following agents were used to achieve suboptimal levels of stimulation. Leukotriene $\mathrm{B}_{4}\left(\mathrm{LTB}_{4}\right)$, (Calbiochem-Behring Corp., La Jolla, CA) was used at $10^{-6}, 10^{-7}$, and $10^{-8} \mathrm{M}$; zymosan-activated serum (ZAS), a source of C5a and C5a des-Arg (18) was used at dilutions of 1:20 to 1:1,000; purified C5a (19), was used at $10^{-7}, 10^{-8}$, and $10^{-9} \mathrm{M}$; supernatants of stimulated human peripheral blood monocytes (20) were used at dilutions from 1:8 to 1:256; and recombinant human tumor necrosis factor (Genentech, Inc., San Francisco, CA) was used at 1-24.5 U/ml. After incubation, cells were washed and prepared for flow cytometry as described above.

To determine the effect of proteases on complement receptor expression, PMN were first incubated with FMLP or ZAS for $30 \mathrm{~min}$, then the designated amount of protease or buffer alone was added and incubation was continued for an additional $30 \mathrm{~min}$. Cells were then washed and prepared for immunofluorescence as described above. The proteases used were from the following sources: human leukocyte elastase was purified as described previously (21); pseudomonas elastase was purchased from Nagase Chemical, Osaka, Japan, or purified as described by Obernesser et al. (22); and bovine pancreatic trypsin was purchased from Sigma. To determine the effects of BAL fluid constituents on complement receptor expression by normal PMN, aliquots of BAL supernatants that had been stored at $-80^{\circ} \mathrm{C}$ were added to PMN in the absence or presence of FMLP and incubated at $37^{\circ} \mathrm{C}$ for $1 \mathrm{~h}$ before being washed and prepared for immunofluorescence staining and flow cytometry as described above. In experiments designed to determine the inhibitor sensitivity of proteases present in the BAL supernatants, aliquots of these fluids were preincubated with various inhibitors or control buffers for $15 \mathrm{~min}$ at $37^{\circ} \mathrm{C}$, and were then mixed with neutrophil suspensions and FMLP was added to a final concentration of $10^{-8} \mathrm{M}$. Incubation was continued at $37^{\circ} \mathrm{C}$ for $1 \mathrm{~h}$. The cells were then washed and handled as described above. The compounds tested included: BSA (ICN, Lisle, IL), $\alpha_{1}$-antitrypsin (Prolastin; Cutter Biologicals, West Haven, CT), 1,10-phenanthrolene (Aldrich Chemical Co., Milwaukee, WI), EDTA, and phosphoramidon (Sigma). These were all freshly dissolved in HBSS-gel and used at the final concentrations indicated in the text. In addition, the serine protease inhibitor PMSF was purchased from Sigma Chemical Co., and stored as a 1-mM stock solution in dried isopropanol.

In experiments with pyocyanine derivatives or trifluoperazine (Smith Kline \& French, Inc., Philadelphia, PA), these compounds were included along with FMLP for the entire 60 min of stimulation. Phenazine was purchased from Sigma Chemical Co. Pyocyanine was prepared by photooxidation of phenazine methosulfate followed by sequential chloroform and aqueous extractions and crystallization from water by the procedure of Knight, as previously described $(23,24)$.

$P M N$ bactericidal activity. A clinical isolate of mucoid $P$. aeruginosa from a CF patient's sputum was subcultured overnight and grown to stationary phase, then washed in PBS and preopsonized by incubation for $45 \mathrm{~min}$ at $37^{\circ} \mathrm{C}$ in $20 \%$ pooled fresh human serum that had been depleted of $\mathrm{C} 5$ by immunoadsorption using anti-human $\mathrm{C} 5$ (Cappel Laboratories). C5 depletion prevents direct bactericidal activity of the serum. These opsonized bacteria ( 2.0 to $2.5 \times 10^{8}$ colony forming units [cfu]) were washed in PBS and resuspended in $1.0 \mathrm{ml}$ of a mixture of equal volumes of HBSS-gel and tryptic soy broth (Difco Laboratories, Detroit, MI). Neutrophils $\left(5 \times 10^{6} / \mathrm{ml}\right)$ that had been preincubated for $30 \mathrm{~min}$ at $37^{\circ} \mathrm{C}$ in HBSS-gel alone or with $10 \mu \mathrm{g} / \mathrm{ml}$ human neutrophil elastase were washed and resuspended in HBSS-gel, then added to the bacteria suspensions to give a final reaction mixture containing $5 \times 10^{6}$ neutrophils in $1.5 \mathrm{ml}$. Aliquots of each mixture were removed immediately and after 30 and 90 min of incubation at $37^{\circ} \mathrm{C}$. The number of viable bacteria in each mixture was determined by serial dilution in distilled water and quantitative spread plating on tryptic soy agar (25), and expressed as colony-forming units per milliliter. The extent of killing of the $P$. aeruginosa by control or elastasetreated PMN at each time interval was then expressed in comparison to the change in colony-forming units per milliliter over the same 
interval for a control mixture that contained HBSS-gel alone, instead of PMN

\section{Results}

Complement receptor expression on peripheral blood neutrophils of cystic fibrosis patients. Before studying inflammatory cells, we first determined whether the peripheral blood neutrophils of cystic fibrosis patients increased complement receptor expression normally in response to stimulation with chemoattractants and whether they were already circulating in an activated state. The preliminary results of nine paired comparisons of isolated peripheral blood neutrophils from CF patients attending our outpatient clinic and healthy controls showed no difference in the baseline state of receptor expression or in the response to FMLP in vitro (26). To further confirm the premise that the neutrophils in CF could upregulate complement receptor expression normally, the results obtained with the peripheral blood cells of each of the CF patients in this study were compared with the results with a normal control donor run on a consecutive day. As shown in Table II, the baseline levels of CR1 and CR 3 expression on the CF patients' neutrophils maintained at $0^{\circ} \mathrm{C}$ were slightly, but not significantly higher than on the controls' cells. The level of expression of each receptor achieved upon optimal stimulation with $10^{-8} \mathrm{M}$ FMLP in vitro was also very similar for CF patients and controls. There was no difference in the baseline or stimulated levels of expression of either CR 1 or CR3 on cells from the CF patients taking steroids or NSAIDs or those not taking any antiinflammatory agent, as shown below. These results suggested that complement receptor expression during neutrophil activation is not affected by the underlying defect in CF and could therefore be used to assess the state of these cells in situ.

Characterization of bronchoalveolar lavage (BAL) cells. As shown in Table I, the cells recovered from the CF patients' lavages were predominantly neutrophils. Using volume and right angle light scatter gates on the flow cytometer set to include both resting and FMLP-stimulated blood PMN from each patient, it was possible to selectively analyze granulocytes in these lavage mixtures without further purification and to obtain data on 10,000 cells for each surface antigen considered. Identity of these cells was confirmed for each lavage sample by determining that they were uniformly negative for HLA-DR, (Fig. $1 A$ ), which is expressed on mononuclear phagocytes and lymphocytes, but not on granulocytes (14); and positive for the marker Leu-11a (Fig. $1 B$ ), which is expressed on neutrophils, but not on mononuclear phagocytes (15). This example is for a BAL sample that contained $60 \%$

Table II. Complement Receptor Expression on Resting and Activated Peripheral Blood PMN of CF Patients and Normal Controls

\begin{tabular}{cccccc}
\hline & \multicolumn{3}{c}{ CR1 } & & \multicolumn{2}{c}{ CR3 } \\
\cline { 2 - 3 } \cline { 5 - 6 } & $0^{\circ} \mathrm{C}$ & FMLP & & $0^{\circ} \mathrm{C}$ & FMLP \\
\hline CF & $1.6 \pm 0.28^{*}$ & $17.9 \pm 2.1$ & & $3.6 \pm 0.53$ & $39.8 \pm 3.9$ \\
NL & $1.3 \pm 0.18$ & $15.1 \pm 1.3$ & & $2.5 \pm 0.28$ & $38.8 \pm 3.1$
\end{tabular}

* Corrected fluorescence, mean \pm SEM, $n=10$.
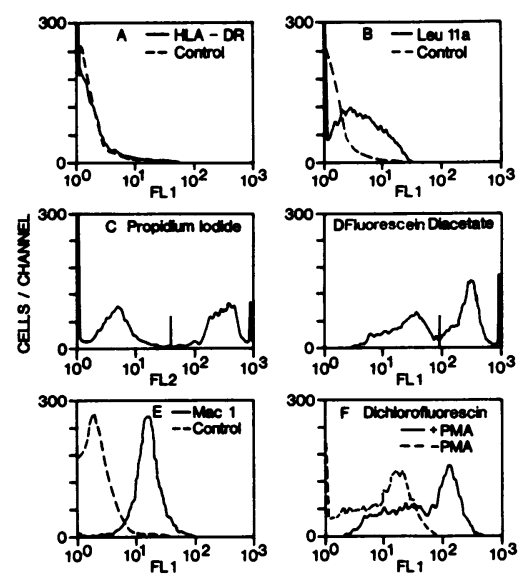

Figure 1. Fluorescence histograms of BAL cells from a $\mathrm{CF}$ patient indicating $(A)$ expression of HLA-DR; $(B)$ expression of leu $11 \mathrm{a} ;(C)$ red fluorescence (FL2) due to propidium iodide; (D) green fluorescence (FL1) due to fluorescein diacetate; $(E)$ CR3 (Macl) expression; $(F)$ green fluorescence (FL1) due to oxidation of dichlorofluorescin. Results shown are for 10,000 cells from each sample. In $A, B$, and $E$ the dashed line shows the histogram for the nonspecific antibody control, as discussed in Methods. In $C$ and $D$, the vertical line is the discriminator set on isolated blood neutrophils. For propidium iodide $(C)$, cells falling to the left of this line would be considered to be excluding the dye (viable), while for fluorescein diacetate $(D)$ cells falling to the right of the line would be considered stained with dye (viable). In $F$, the dashed line is for the control that was not stimulated with PMA.

PMN and 40\% macrophages. Comparable data could not be obtained on lavages of normal donors, which contained $<5 \%$ PMN in most cases.

Although we did not determine the viability of the lavage PMN during this set of experiments, data on comparable lavages from five similar CF patients, which contained a mean of $78 \%$ PMN, indicated that $60 \pm 2 \%$ (mean \pm SEM) of the lavage PMN were viable as determined by flow cytometry using the two criteria of exclusion of propidium iodide and uptake and retention of fluorescein diacetate (16), as shown in Fig. 1, $C$ and $D$. In most cases, the values obtained with these two indicators were within 5\% of each other. The use of these fluorescent dyes rather than conventional vital stains such as trypan blue allowed us to selectively analyze only the neutrophils in the mixtures of lavage cells since the volume and light scatter gates on the flow cytometer excluded small fragmented cells and macrophages. It is interesting that despite the fact that these dye studies show that the lavage PMN contain a large subpopulation of cells with some compromise of membrane integrity, no such subpopulation is evident in the histogram for CR3 expression on the same cells (Fig. $1 E$ ), which is quite symmetric and uniform.

The functional capabilities of the lavage PMN were assessed by determining their ability to produce an oxidative respiratory burst in response to stimulation with PMA. This was done using the indicator dichlorofluorescin diacetate, which is taken up by cells but becomes fluorescent only after oxidation (17). This fluorescent method facilitates analysis of only those cells being analyzed for receptor expression, and allows determination of the percentage of pertinent cells responding rather than just the amount of product such as $\mathrm{O}_{2}^{-}$or $\mathrm{H}_{2} \mathrm{O}_{2}$ formed. An example of the shift in fluorescence after stimulation is shown in Fig. $1 F$. Subtraction of the histogram of unstimulated cells from that for the stimulated cells shows that $52 \%$ of the cells increased fluorescence in response to phorbol ester. For this series of patients, the percentage of cells responding in this way, $54.9 \pm 4.3 \%$, was in close agreement 
with the percentage of cells considered viable by the membrane integrity criteria. The fact that these cells responded to PMA with a respiratory burst in vitro is consistent with previous reports demonstrating that PMN that have already responded to chemoattractants in vivo or in vitro retain the ability to produce $\mathrm{H}_{2} \mathrm{O}_{2}$ in response to additional stimuli (10).

Complement receptor expression on inflammatory neutrophils. Representative fluorescence histograms for CR3 expression on lavage and peripheral blood neutrophils from one patient are shown in Fig. $2 A$. As can be seen, the isolated peripheral blood cells behave as a single uniform population, although there is a large shift in the fluorescence of the cells stimulated with $10^{-8} \mathrm{M}$ FMLP as compared with the resting cells maintained at $0^{\circ} \mathrm{C}$. The histogram for the lavage cells, which were also handled at $0^{\circ} \mathrm{C}$, shown in the solid line, also shows a relatively uniform population which is almost superimposeable on the histogram for the FMLP-stimulated peripheral blood cells. This observation suggested that the neutrophils in the lung were nearly maximally activated in vivo. The results on the same cells stained for $\mathrm{CR} 1$ fluorescence are shown in Fig. $2 \mathrm{~B}$. Again, both the resting $\left(0^{\circ} \mathrm{C}\right)$ and FMLPactivated isolated peripheral blood cells appear to be homogenous populations with a large shift in the fluorescence of the latter. In contrast to the results for CR3 staining, however, the results for staining of $\mathrm{CR} 1$ on the lavage cells show a much broader pattern with a mean fluorescence only slightly higher than that of the resting blood cells. Similar results were obtained for the other patients as well, and the results are summarized in Fig. 3 and Table III. For each receptor, comparisons of the mean fluorescence of the lavage cells with resting and activated blood cells are shown in Fig. 3. There was no difference between the results obtained with cells from patients taking corticosteroids or NSAIDs, shown in the closed symbols, and those from patients not taking any antiinflammatory agent, shown in the open symbols. It is readily apparent that for CR3, the lavage cells much more closely resembled the activated blood cells than the resting blood cells, while for CR 1 the opposite was true. This was studied in more detail by comparing each patient's lavage cells with his or her own resting and activated blood cells. In the upper part of Table III, the results presented are the mean of the values for each patient of

A CR3

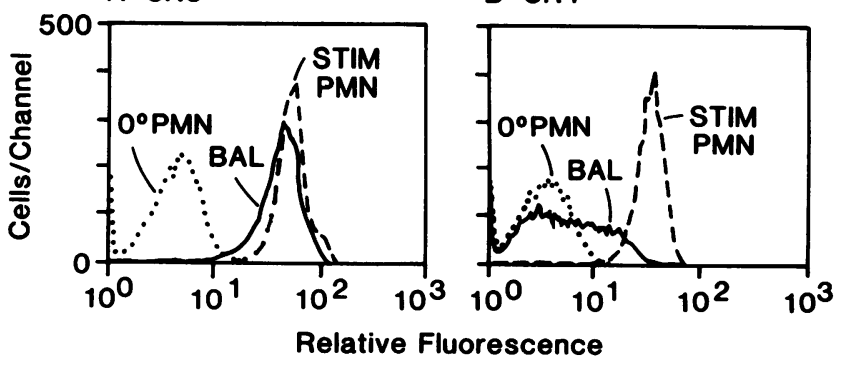

Figure 2. Fluorescence histograms for CR3 $(A)$ and CR1 $(B)$ expression on peripheral blood and lavage neutrophils. Each curve represents 10,000 cells. Resting blood cells $(\cdots)$ were maintained at $0^{\circ} \mathrm{C}$ after isolation, stimulated blood cells (- - ) were incubated with $10^{-8} \mathrm{M}$ FMLP at $37^{\circ} \mathrm{C}$ for $60 \mathrm{~min}$. Lavage cells (-) were maintained at $0^{\circ} \mathrm{C}$. All cell suspensions were aliquoted for staining with anti-CR 1 or anti-CR3, washed and prepared for flow cytometry in parallel as described in Methods.
A CR1

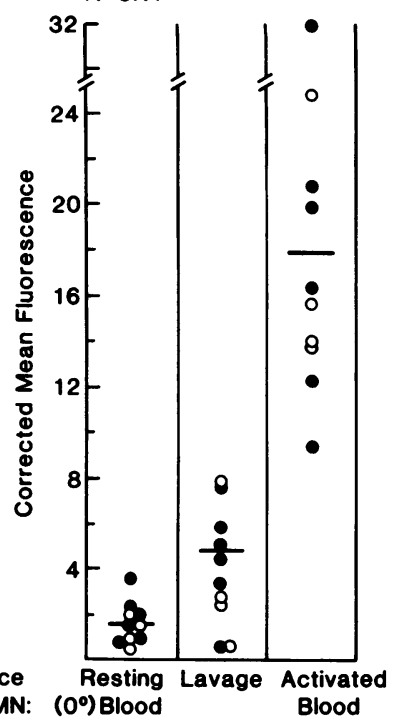

B CR3

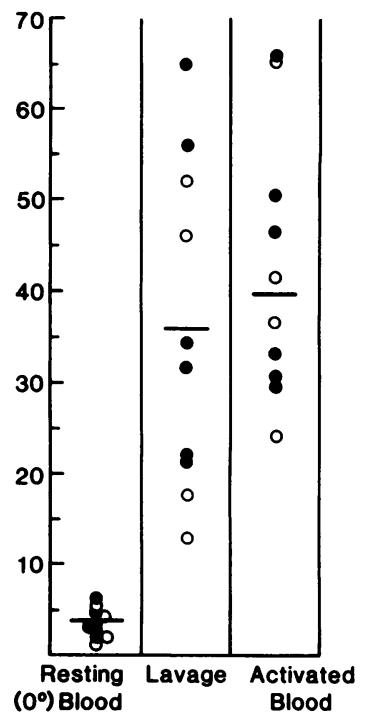

Figure 3. Summary of mean fluorescence values for CR1 $(A)$ and CR3 $(B)$ expression on resting blood neutrophils, lavage cells, and FMLP stimulated blood neutrophils from cystic fibrosis patients. All values are the means for 10,000 cells from each sample after background correction by subtraction of nonspecific fluorescence as described in Methods. •, Patients taking corticosteroids or nonsteroidal antiinflammatory drugs. $O$, Patients not taking antiinflammatory agents. The horizontal line through each group indicates the mean.

the fluorescence of: lavage cells $\div$ resting peripheral blood cells; or FMLP stimulated $\div$ resting blood cells. In the lower part of the table, the results for resting blood cells $\div$ FMLPstimulated blood cells and lavage cells $\div$ FMLP-stimulated blood cells are given. Again, it is apparent that the level of expression of CR3 on the lavage cells closely approximates the level of CR3 expression achieved when the isolated peripheral blood cells were stimulated optimally in vitro with FMLP. In contrast, although resting cells expressed similar fractions of their maximal CR 1 and CR3 expression, 0.093 and 0.089 respectively; and the upregulation of the two receptors upon stimulation in vitro was also similar, 13.5-fold for CR 1 and 12.8-fold for CR3; the amount of CR1 expressed on lavage cells was substantially lower. CR 1 expression on lavage cells was only 0.27 of that on blood cells stimulated with FMLP. This represents only a 3.1-fold increase over the level of CR 1 on resting cells, which is dramatically lower than the 13.5-fold increase achieved with FMLP in vitro.

A similar discrepancy between the degree of upregulation of CR1 and CR3 was also found for bronchoalveolar lavage neutrophils obtained from a child with chronic $P$. aeruginosa infection unrelated to cystic fibrosis. In this child the level of CR1 expressed on lavage cells was only $30 \%$ as high as on FMLP stimulated blood cells, while the expression of CR3 on the lavage cells was $102 \%$ of the level achieved with stimulation in vitro. A comparable situation was also found in four samples of joint fluid from patients with inflammatory arthritides, in which the mean CRI expression was $24.3 \%$ of that found with FMLP treatment of peripheral blood cells, while the CR3 expression was $55 \%$ of the level on the cells stimulated in vitro $(P<0.01)$.

Although the lavage cells appeared to be markedly activated in vivo, as indicated by their high level of CR3 expres- 


\begin{tabular}{|c|c|c|c|c|}
\hline \multirow[b]{3}{*}{ Ratio to $0^{\circ} \mathrm{C}$ blood $\mathrm{PMN}$} & \multicolumn{2}{|r|}{ CR1 } & \multicolumn{2}{|r|}{ CR3 } \\
\hline & Lavage PMN & FMLP stimulated Blood PMN & Lavage PMN & FMLP stimulated Blood PMN \\
\hline & $3.1 \pm 0.81^{*}$ & $13.5 \pm 2.1$ & $11.0 \pm 1.7$ & $12.8 \pm 1.5$ \\
\hline & Lavage PMN & $0^{\circ} \mathrm{C}$ Blood PMN & Lavage PMN & $0^{\circ} \mathrm{C}$ Blood PMN \\
\hline Ratio to FMLP-stimulated blood PMN & $0.27 \pm 0.08^{\ddagger}$ & $0.093 \pm 0.017$ & $0.90 \pm 0.12$ & $0.089 \pm 0.012$ \\
\hline
\end{tabular}

${ }^{*} P<0.001$ for comparisons with CR1 on FMLP stimulated blood PMN and CR3 on lavage PMN $(n=10)$. ${ }^{\ddagger} P<0.05$ for comparison with $\mathrm{CR} 1$ on $0^{\circ} \mathrm{C}$ blood PMN and $<0.001$ for comparison with CR3 on lavage PMN $(n=10)$.

sion, we attempted to further stimulate these cells with FMLP in vitro in order to determine if this would raise their level of CR 1 expression. Incubation of lavage cells with $10^{-8} \mathrm{M}$ FMLP in vitro did increase both CR1 and CR3 slightly as compared to the level of expression of these receptors on similarly stimulated blood cells, but the relative amount of CR1 expressed remained significantly less than CR3, as shown in Fig. 4.

Proportionality of $C R 1$ and $C R 3$ expression in response to different stimuli. We considered the possibility that the difference in behavior of CR1 relative to CR3 on cells from the inflammatory sites in vivo compared to those stimulated in vitro with FMLP might be related to the type or degree of stimulus they encountered physiologically. To determine whether other stimuli increased CR1 and CR3 expression in different proportions than FMLP, we compared the expression of these two receptors in response to varying concentrations of each of several stimuli that they might encounter in vivo. These included: zymosan-activated serum, a source of C5a des-Arg; purified C5a; $\mathrm{LTB}_{4}$; tumor necrosis factor; and monocyte supernatants. The results are presented in Fig. 5, with the expression of each receptor shown as the ratio of the mean fluorescence for that receptor under the experimental condition to the mean fluorescence for that receptor on cells

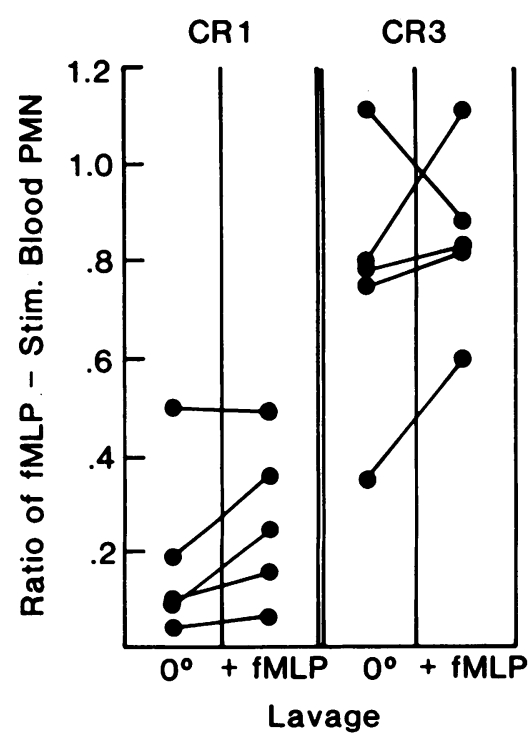

Figure 4. Effects of FMLP treatment of lavage cells in vitro on expression of CR1 (left) and CR3 (right). Lavage cells were maintained in HBSS/gel at $0^{\circ} \mathrm{C}$ or incubated with $10^{-8} \mathrm{M}$ FMLP at $37^{\circ}$ for $1 \mathrm{~h}$. Peripheral blood cells from the same patients were incubated with FMLP in parallel. All samples were then washed, stained and prepared for flow cytometry. Results are expressed as the ratio of the corrected mean fluorescence for each receptor on $0^{\circ} \mathrm{C}$ or FMLP treated lavage cells di-

vided by the corrected mean fluorescence for that receptor on FMLP stimulated peripheral blood cells from the same patient. This study was performed on the second lavages of patients 2 and 4 , and on the lavages of patients 3,6 , and 7 . stimulated in parallel with $10^{-8} \mathrm{M}$ FMLP. It is apparent that the same proportionality of $C R 1$ and CR3 upregulation that occurs in response to FMLP also occurs with all doses of the other stimuli, since the results closely fit a linear regression line with a slope of 1.0. In contrast, the results for the BAL cells all fall below the line, confirming the decreased amount of CR1 expressed compared with CR3.

Taken together with the inability of further stimulation with FMLP in vitro to significantly raise the CR1 level on the inflammatory cells, these findings suggested that the decreased CR 1 expression was not due to suboptimal stimulation in vivo. We therefore considered it likely that the observed results

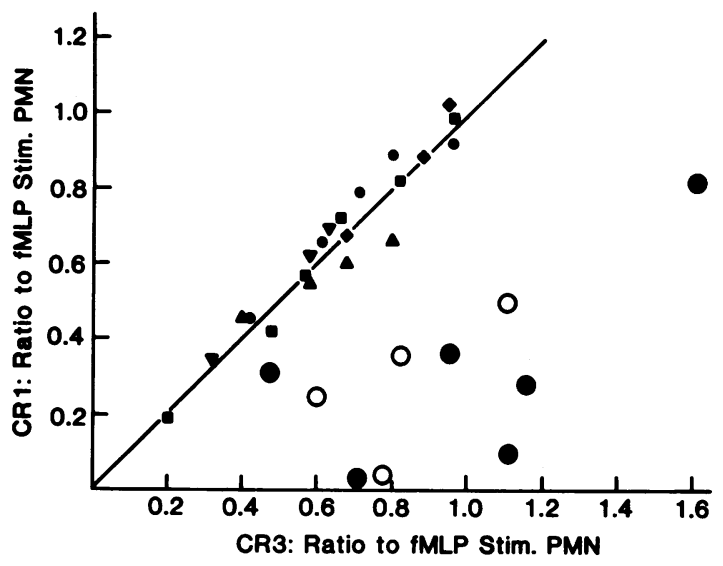

Figure 5. Proportionality of upregulation of CR1 and CR3 on neutrophils stimulated in vitro compared to lavage cells. Isolated peripheral blood cells from normal donors were stimulated in vitro with $10^{-8} \mathrm{M}$ FMLP or the indicated stimulus for $60 \mathrm{~min}$ and then stained for CR1 and CR3 fluorescence as described in Methods. Corrected mean fluorescence for each receptor on cells from each experimental condition was then divided by the corrected mean fluorescence for that receptor on cells from the same donor incubated with FMLP. The ratios thus obtained are plotted for each experimental condition, with CR1 on the ordinate and CR3 on the abscissa. Experimental stimuli and their final concentrations were: purified C5a ( $\bullet) 10^{-7}$, $10^{-8}$, and $10^{-9} \mathrm{M}$; zymosan activated serum ( $(\bullet), 1: 20,1: 50,1: 100$, $1: 200,1: 300,1: 1,000$; recombinant tumor necrosis factor $(\Lambda)$ 1, 2.5, 10 , and $24.5 \mathrm{U} / \mathrm{ml}$; stimulated monocyte supernatant $(\bullet) 1: 8,1: 32$, $1: 64,1: 128$ and 1:256; or $\operatorname{LTB}_{4}(v) 10^{-8}, 10^{-7}, 10^{-6} \mathrm{M}$. Linear regression analysis of these points gave a slope of $1.00 \pm 0.06$ and correlation coefficient $(r)$ of 0.96 . Ratios of receptor expression on lavage cells maintained at $0^{\circ} \mathrm{C}$ compared to the patient's peripheral blood cells stimulated with FMLP were calculated in the same way and are shown as the larger symbols. Closed symbols are for CF patients taking corticosteroids or NSAIDs, open symbols are for patients not taking antiinflammatory drugs. 
may have been due to other factors present in the inflammatory milieu. The experiments described below were then performed in order to test various possible constituents of the lavage fluid for their effects on CR1 vs. CR3 expression in vitro.

Effects of Pseudomonas pigments and bacterial and leukocyte proteases on complement receptor expression in vitro. $P$. aeruginosa is the predominant pathogen responsible for chronic pulmonary infection in $\mathrm{CF}$. We therefore explored the possibility that one of its exoproducts was responsible for the relative deficiency in CR1 expression we observed. Pseudomonas organisms secrete a number of phenazine pigments, including pyocyanine, which have been shown to decrease lymphocyte activation and to inhibit expression of the IL-2 receptor $(27,28)$. Pyocyanine has also been shown to inhibit $\mathrm{O}_{2}^{-}$production by PMN (26). These pigments are structurally similar to the phenothiazines, which have previously been shown to inhibit complement receptor upregulation during neutrophil activation (29). For this reason, we first tested the possibility that phenazines might also inhibit receptor expression on neutrophils and that this might contribute to the decreased CR1 expression we observed on the bronchoalveolar lavage cells. As shown in Fig. 6, the naturally occurring compound pyocyanine, and phenazine, at concentrations as high as $50 \mu \mathrm{M}$, failed to inhibit the FMLP induced upregulation of $\mathrm{CR} 1$ and CR3. In contrast, phenazine methosulfate, a synthetic intermediate used for the in vitro preparation of pyocyanine, did cause inhibition at this concentration, while the phenothiazine, trifluoperazine, caused $>50 \%$ inhibition at 5 $\mu \mathrm{M}$, in agreement with our previous findings (29). The lack of

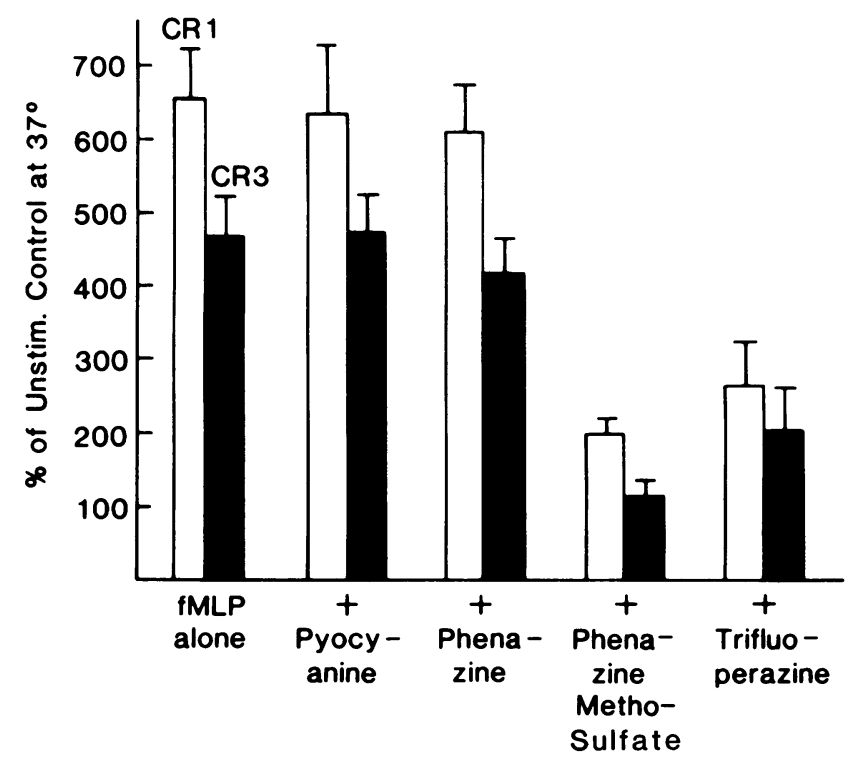

Figure 6. Effect of $P$. aeruginosa pigments and related compounds on FMLP induced increased complement receptor expression on peripheral blood neutrophils. Isolated PMN were incubated at $10^{6}$ cells $/ \mathrm{ml}$ for $1 \mathrm{~h}$ at $37^{\circ} \mathrm{C}$ with $10^{-8} \mathrm{M}$ FMLP alone or with $50 \mu \mathrm{M}$ pyocyanine, phenazine, or phenazine methosulfate, or $5 \mu \mathrm{M}$ trifluoperazine. After incubation, aliquots were removed, washed and stained for CR1 and CR3 fluorescence as described in Methods. Results shown are the mean \pm standard error for three experiments. Results for phenazine methosulfate and trifluoperazine differ from FMLP alone with $P<0.05$. inhibition by the naturally occurring compounds under conditions where other compounds with somewhat similar structures were markedly inhibitory suggests that phenazines are not involved in the decreased CR1 expression we observed.

Since it is known that $\mathrm{C} 3 \mathrm{~b}$ dependent rosetting and immune adherence reactions are sensitive to proteases $(30,31)$ we next determined whether these enzymes were responsible for our observations. Isolated peripheral blood neutrophils were stimulated with $10^{-8}$ M FMLP or with an optimal dilution of zymosan-activated serum (ZAS) but after $30 \mathrm{~min}$, various amounts of proteases or buffer alone were added and incubation was continued to complete $60 \mathrm{~min}$. The cells were then washed using our standard solution, which contains the protease inhibitor PMSF, and prepared for flow cytometry. As shown in Fig. 7, a variety of protease preparations were tested, including trypsin, purified pseudomonas elastase, and purified neutrophil elastase. All of these preparations gave similar results: dose-dependent reduction in CR 1 expression with little or no effect on CR3 expression. At the higher inputs of the purified enzymes, CR 1 expression was reduced to below the level on the unstimulated control cells. These results thus suggest that our observations on the bronchoalveolar lavage cells could be due to the attack of proteases on the cells, with resultant cleavage of CR1 but not CR3.

In vitro effects of lavage fluid supernatants. Incubation of isolated peripheral blood PMN from a normal donor in the bronchoalveolar lavage supernatant of a pseudomonas-infected CF patient increased CR 1 expression to a level twice as high as on cells held at $37^{\circ} \mathrm{C}$ in buffer alone, but increased CR3 expression on the same cells threefold, as shown at the left of Fig. 8. This relatively lower degree of upregulation of CR1 was analogous to what had been observed on fresh lavage neutrophils from CF patients. Since the results in the previous section suggested that this might be due to proteases, we determined the effect of preincubating the lavage fluid with the serine-protease inhibitor PMSF. When the neutrophils were incubated with the lavage fluid containing this compound, both receptors were upregulated to the same level. Comparable results were obtained when $10^{-8}$ M FMLP was also included, but the maximal level of receptor upregulation was about sixfold higher than on cells in buffer alone. Lavage fluid reduced the CR 1 expression to only fourfold without affecting the increase in CR3 expression. Pretreatment of the lavage fluid with PMSF eliminated this selective effect on CR1 expression. Incubation of isolated neutrophils with supernatants of lavage fluid from normal donors, both smokers and nonsmokers ( $n$ $=4$ ), did not cause upregulation of CR 1 or CR3 and did not reduce the amount of CR1 expressed when FMLP was also present (not shown in figure).

To further define the specificity of the effects of protease inhibitors and thereby identify the enzyme(s) in BAL supernatant responsible for cleaving CR1, we determined whether other inhibitors could also block the reduction of $\mathrm{CR} 1$ on FMLP-treated PMN caused by BAL supernatants from CF patients. As shown in Table IV, only $\alpha_{1}$-antitrypsin and PMSF inhibited the cleavage of CR1. Bovine serum albumin, included as a control for nonspecific effects of protein; the chelators EDTA and phenanthrolene; and phosphoramidon, which specifically inhibits $P$. aeruginosa elastase, were all without effect. These results strongly suggest that a serine protease, most likely neutrophil elastase, is responsible for the cleavage of CR1 we observed. 


\section{A. TRYPSIN}

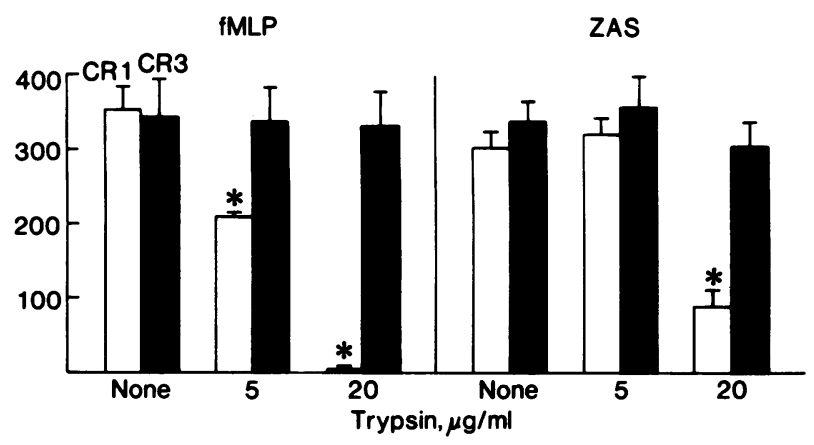

B. PSEUDOMONAS ELASTASE

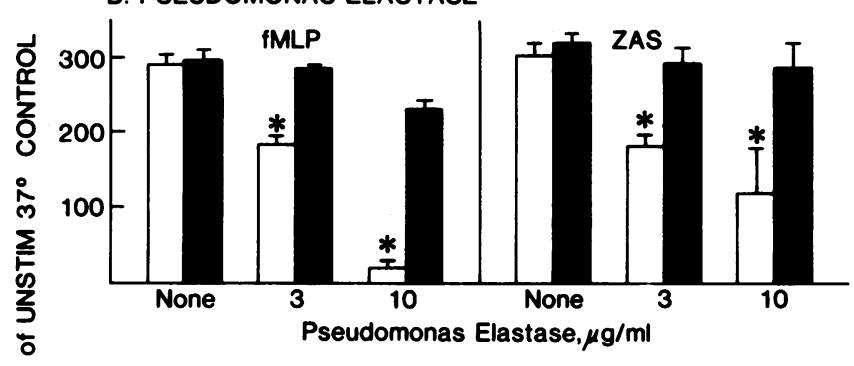

C. HUMAN LEUKOCYTE ELASTASE

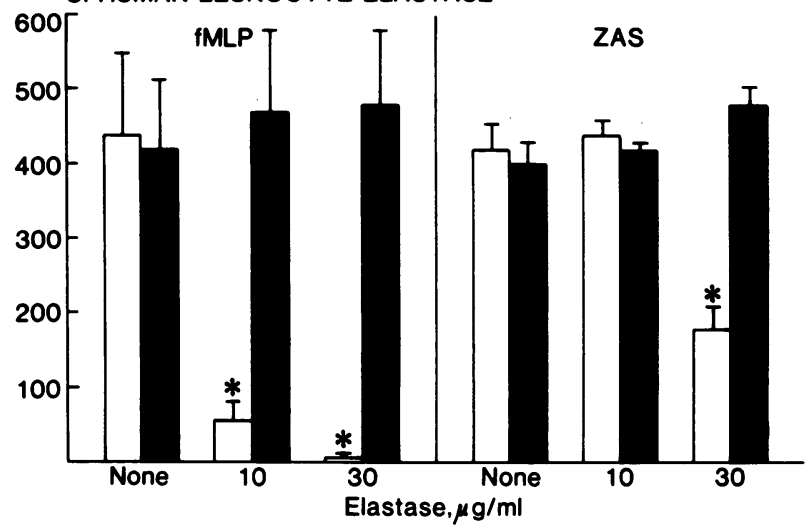

Figure 7. Effects of proteases on CR1 and CR3 expression on isolated peripheral blood neutrophils. Isolated $P M N$ at $10^{6} / \mathrm{ml}$ were incubated with $10^{-8}$ M FMLP (left half of each panel) or with zymosan-activated serum (ZAS) at a final concentration of $1 \%$ (right half of each panel). After $30 \mathrm{~min}$, various amounts of the indicated proteases were added in a small volume of HBSS/gel and incubation was continued for an additional $30 \mathrm{~min}$. Cells were then washed, aliquoted and prepared for flow cytometry. Results shown are the mean and standard error for three to five experiments. ${ }^{*} \mathrm{CR} 1$ is less than CR1 on the corresponding FMLP alone or ZAS alone sample with $P<0.05$. There were no significant differences in CR3 expression.

Effect of elastase treatment on PMN bactericidal activity. Since our results suggested that lavage and other inflammatory neutrophils had undergone cleavage of CR1 due to the exposure to neutrophil elastase in vivo, we attempted to determine what effects this might have on the bactericidal activity of the normal neutrophils. As can be seen in Fig. 9, untreated control neutrophils reduced the number of viable $P$. aeruginosa by almost 2 logs at $30 \mathrm{~min}$ and by 3 logs at $90 \mathrm{~min}$ as compared to equivalent incubations without neutrophils. In contrast, neutrophils which had been pretreated with elastase under conditions sufficient to remove $\sim 70-80 \%$ of their CR1 (Fig. 7) showed very little killing at $30 \mathrm{~min}$ and much less killing at 90

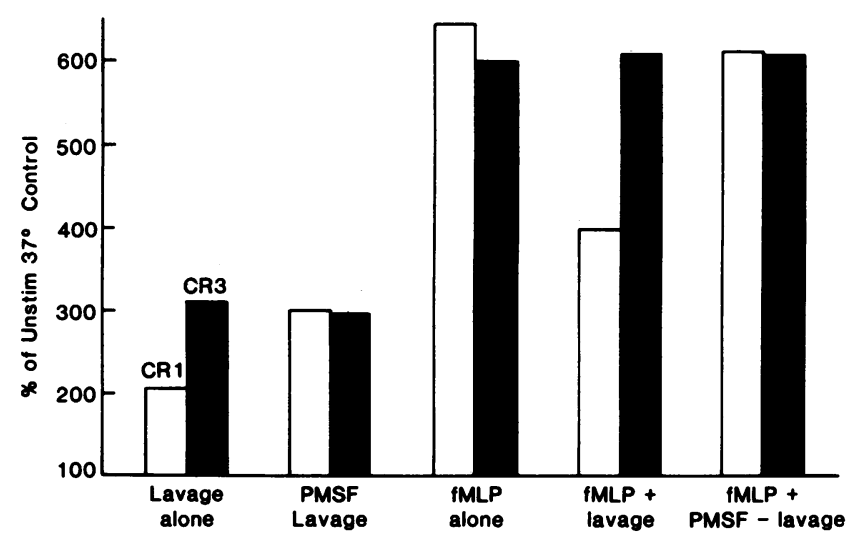

Figure 8. Effect of bronchoalveolar lavage supernatant on complement receptor expression on isolated peripheral blood neutrophils. Aliquots of bronchoalveolar lavage fluid supernatant were preincubated with $1 \mathrm{mM}$ PMSF or the equivalent amount of isopropanol $(1 \%)$ for $15 \mathrm{~min}$ at $37^{\circ} \mathrm{C}$. Lavage fluid samples $(0.3 \mathrm{ml})$ were then mixed with $0.7 \mathrm{ml}$ of $\mathrm{HBSS} / \mathrm{gel}$ and $0.2 \mathrm{ml}$ of a suspension of isolated PMN at $10^{7} / \mathrm{ml}$. Designated mixtures contained a final concentration of $10^{-8} \mathrm{M}$ FMLP. All mixtures were incubated at $37^{\circ} \mathrm{C}$ for 1 $h$ then the cells were washed, aliquoted, and prepared for flow cytometry. A single representative experiment is shown.

min than the untreated neutrophils. Similar results were obtained with nonmucoid stains of $P$. aeruginosa. These results strongly suggest that exposure to neutrophil elastase at inflammatory sites in vivo may markedly impair the bactericidal activity of the neutrophils.

\section{Discussion}

Neutrophils in the circulation bear relatively few complement receptors or adhesion molecules. Activation of these cells is accompanied by a rapid increase in the surface expression of these proteins, a process that is believed to be necessary for

Table IV. Effect of Protease Inhibitors on Degradation of Human Neutrophil CRI by CF Bronchoalveolar Lavage Supernatant

\begin{tabular}{lrc}
\hline \multicolumn{1}{c}{ Inhibitor } & \multicolumn{1}{c}{ CR1: \% of control in FMLP alone } \\
\hline & Mean \pm SEM & \\
HBSS $(5 \%)$ & $55.5 \pm 8.4$ & \\
BSA $(50 \mu \mathrm{g} / \mathrm{ml})$ & $55.8 \pm 8.4$ & \\
$\alpha$-IAT $(25 \mu \mathrm{g} / \mathrm{ml})$ & $92.6 \pm 2.2$ & \\
EDTA $(5 \mathrm{mM})$ & $60.6 \pm 5.7$ & \\
Phenanthrolene $(1 \mathrm{mM})$ & $60.3 \pm 6.6$ & \\
Phosphoramidon $(0.2 \mathrm{mM})$ & $50.3 \pm 5.9$ & \\
Isopropanol $(1 \%)$ & $50.2 \pm 6.8$ & $P<0.001$ \\
PMSF $\left(10^{-3} \mathrm{M}\right)$ & $100.4 \pm 2.0$ &
\end{tabular}

Aliquots of lavage supernatant were preincubated with the indicated reagent for $15 \mathrm{~min}$ at $37^{\circ} \mathrm{C}$. Lavage samples $(0.3 \mathrm{ml})$ were then mixed with $0.7 \mathrm{ml}$ of HBSS- $0.1 \%$ gelatin and $0.2 \mathrm{ml}$ of a suspension of isolated peripheral blood PMN at $10^{7} / \mathrm{ml}$. FMLP was then added to each mixture, to a final concentration of $10^{-8} \mathrm{M}$, and the mixtures were incubated at $37^{\circ} \mathrm{C}$ for $1 \mathrm{~h}$. Results are shown and mean \pm SEM for two to three experiments with each of two different lavage supernatants. $P$ values are for the difference between the condition indicated and the relevant control, HBSS alone for $\alpha_{1}$-antitrypsin $(\alpha-1 \mathrm{AT})$ and $1 \%$ propanol for PMSF. 


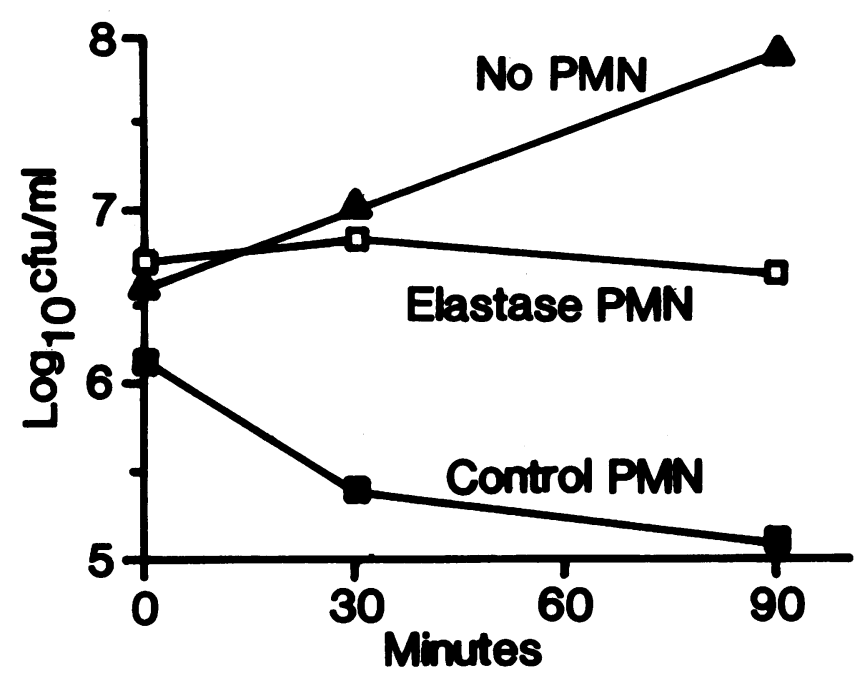

Figure 9. Killing of opsonized $P$. aeruginos $a$ by elastase treated and control PMN. Viable $P$. aeruginosa, expressed as $\log _{10}$ colony forming units $(\mathrm{cfu}) / \mathrm{ml}$, increased in the absence of PMN ( $\mathbf{\Delta})$. The effects of PMN pretreated with $10 \mu \mathrm{g} / \mathrm{ml}$ human leukocyte elastase for 30 min are shown by $\square$ and for control PMN preincubated in HBSS-gel alone are shown by $\boldsymbol{m}$. Results are for a single representative experiment.

adherence to the endothelium, migration of the cells into tissues, and efficient phagocytosis of complement-coated particles. Indeed, deficiency of CR3, the protein that serves as the iC $3 \mathrm{~b}$ receptor as well as the major PMN adherence molecule, is associated with severe local infections that may occur in the face of extremely elevated numbers of circulating PMNs (6). This is consistent with the inability of the deficient PMNs to marginate and follow chemotactic gradients into the tissues. Previous studies have shown that PMNs exposed in the circulation to high levels of complement-derived neutrophil activating peptides such as $\mathrm{C5a}$ and $\mathrm{C5a}$ des-Arg did have increased expression of CR1 and CR3 (7-9). In addition, upregulation of CR3 on neutrophils migrating into experimental skin chambers has also been documented $(10,11)$. However, data on the extent of upregulation of these receptors on cells that had migrated into naturally occuring inflammatory sites are not available. In the present study, we examined the response of PMNs in a physiologic model of localized inflammation, the pseudomonas-infected lung in cystic fibrosis. The patients studied had no clinical evidence of disseminated infection or systemic complement activation. Their peripheral blood PMN did not show significantly increased levels of expression of either CR1 or CR3, suggesting that contact of chemoattractants with the cells and subsequent increased adherence of the cells occurred primarily locally, presumably in the pulmonary capillaries. This is apparently an efficient process, as activated cells did not continue to circulate. By examining neutrophil-rich inflammatory fluids, we were able to take advantage of the ability of the flow cytometer to discriminate these cells by their volume and light scattering characteristics and to selectively analyze this cell type without purification or extensive in vitro handling that might have altered their receptor expression. We have previously shown that both resting and activated PMN retain their levels of $C R$ expression when held in vitro at $0^{\circ}(3)$ and therefore used that condition to be sure that our observations would accurately indicate the state of the cells in situ. Although a significant percentage of the lavage PMN have increased membrane permeability for small molecules such as propidium iodide and fluorescein diacetate, it seems likely that their membranes are grossly intact as evidenced by the uniformity and symmetry of the CR3 histograms.

Our results clearly show that the CR1 expression on the lavage neutrophils is much lower than would be expected based on the amount of CR3 expressed. In fact, the degree of expression of the latter receptor in vivo is remarkably similar to that induced under optimal conditions of stimulation in vitro $\left(10^{-8} \mathrm{M}\right.$ FMLP), suggesting that the cells in these inflammatory exudates are in a similar state of activation. The decreased expression of CR 1 does not appear to be related to the degree or type of stimulus per se that the cells encountered in vivo since a wide variety of physiologic stimuli all increase the expression of both receptors in a relatively constant proportion, as shown in Fig. 5. Furthermore, although the inflammatory cells did respond to FMLP in vitro, the CR1 expression still remained disproportionately low, suggesting that incomplete stimulation of expression was not responsible and that the total cellular pool of CR1 might be depleted. Although they may have a variety of other effects on the inflammatory process, neither corticosteroids nor the NSAID piroxicam appeared to have major effects on receptor expression on the cells that did migrate into the inflammatory site, since the results with patients taking these drugs did not differ from the results with patients not taking any antiinflammatory agent.

Our observations do not appear to be related to the underlying defect in cystic fibrosis, as the peripheral blood cells of these and a previously studied group of CF patients (26) upregulated receptor expression normally in vitro. In addition, results with lavage cells from a child with non-CF chronic $P$. aeruginosa pulmonary infection and results with cells obtained by arthrocentesis from patients with sterile inflammatory arthritides also showed a similar disproportion in CR1 vs. CR3 expression. It is not likely that immune complexes in the inflammatory fluid caused selective blocking or loss of CR1 alone, since such complexes would also be likely to contain iC $3 b$, which would interact with CR3, and IgG which would interact with Fc receptors. Mixing purified neutrophils with aliquots of lavage fluid that had been stored at $-80^{\circ}$ did not result in blocking of these receptors and any immune complexes that might have been carried by the lavage cells would most probably have been removed from the cells by the in vitro washes, since $\mathrm{CR} 1$ and $\mathrm{CR} 3$ are relatively low affinity receptors (32-34). Contaminating macrophages are not a likely cause of the observed differences between CR1 and CR3 expression because the analysis gates set on the flow cytometer effectively excluded macrophages, as evidenced by the lack of HLA-DR positive cells (Fig. 1). Furthermore, results from several other laboratories (35-37) as well as our own unpublished observations indicate that human alveolar macrophages express very little CR3. Although we have recently shown that some internal degradation of CR1 accompanies neutrophil activation, that phenomenon does not appear to decrease surface expression and is not associated with release of supernatant factors that can remove CR1 from fresh neutrophils (38). Because the pattern of CR1 and CR3 expression observed on inflammatory neutrophils can be readily reproduced by treating peripheral blood cells with lavage supernatants, we conclude these findings represent a different phenomenon, probably caused by proteases in the lavage fluid. 
Since we had previously shown that phenothiazines inhibit CR1 and CR3 expression (29), we considered it possible that the chemically similar phenazine pigments produced by pseudomonas might contribute to the decreased CR1 expression we observed. Evidence against a role for these low molecular weight pseudomonas products in limiting CR 1 expression was obtained by testing pyocyanine and phenazine in vitro. Although these pigments are capable of inhibiting lymphocyte activation and block expression of the IL-2 receptor $(27,28)$, they did not block complement receptor expression during neutrophil activation.

Our in vitro experiments suggest that proteases could be the major factors responsible for the decreased CR1 expression, since these enzymes are clearly capable of cleaving this receptor in vitro. It has recently been proposed that proteolysis is responsible for decreasing CR1 expression during ageing of erythrocytes (39). Although it is recognized that C3b dependent rosetting is sensitive to trypsin and other serine proteases $(30,31)$, it has not been previously shown that CR3 is resistant to such enzymes. Since the monoclonal antireceptor antibodies that we used are specific for the ligand binding sites of the respective receptors, our results probably reflect the ligand binding capacities of the cells as they were in situ. Previous studies have demonstrated both active and complexed proteases in lavage supernatants from CF patients (40-45), and it has been proposed that neutrophil elastase in the lung fluid is responsible for fragmentation of IgG in situ $(43,45)$. Although our results with purified enzymes indicate that both neutrophil and pseudomonas elastases are capable of cleaving CR1, the results of experiments with lavage fluid supernatants show that their anti-CR1 effect is eliminated by treatment with PMSF, and $\alpha_{1}$-antitrypsin but not by the metalloprotease inhibitors EDTA or phenanthrolene, nor by phorsphoramidon, a highaffinity inhibitor of pseudomonas elastase (46). This suggests that PMN elastase, which is a serine-dependent enzyme (47), rather than pseudomonas or macrophage elastase, which are metalloproteases $(46,48,49)$ is responsible for the cleavage of CR1. This result is also consistent with previous studies showing that PMN elastase is the major protease remaining active in CF lavage supernatants (40-45). Together with the fact that cells from sterile, PMN-rich inflammatory sites also appear to have undergone similar cleavage, these results strongly support the conclusion that PMN elastase may be the major enzyme responsible for our observations.

The pathogenesis of chronic pulmonary infection in cystic fibrosis remains obscure. Although our results are probably unrelated to the primary genetic defect, we consider it likely that proteolytic degradation of $\mathrm{C} 3 \mathrm{~b}$ receptors may contribute to inability of CF patients to eradicate infectious agents, especially pseudomonas, from their lungs. This conclusion is strongly supported by our observation that elastase treatment of isolated PMN severely impaired their ability to kill opsonized $P$. aeruginosa (Fig. 9). This is not likely to be due to effects on other receptors, since this treatment does not effect CR3, and we have previously shown that it does not affect $F c$ receptor mediated phagocytosis or neutrophil activation (50). Several cell types including monocytes, macrophages, B lymphocytes, and some $\mathrm{T}$ lymphocytes all carry the same $\mathrm{C} 3 \mathrm{~b}$ receptor (51). It thus seems likely that proteolytic attack may cleave this molecule from those cells as well, possibly decreasing the phagocytic activity of monocytes and macrophages and inter- fering with proper immunologic homeostasis of the affected lymphocytes. Fick et al. have presented evidence that neutrophil elastase in the lung may cleave antipseudomonas IgG, rendering it opsonically ineffective (43). This may in part explain other observations that antipseudomonas antibodies in CF have antiopsonic activity (52-54). It has also been shown that PMN elastase may cleave antigen bound IgG and interfere with the activation of phagocytic cells by immune complexes (45). Since C3 fragments and IgG normally have synergistic effects in promoting phagocytosis $(55,56)$, the impaired activity of IgG in CF would place even more emphasis on the necessity for optimal interactions between the complementderived opsonic ligands, $\mathrm{C} 3 \mathrm{~b}$ and $\mathrm{iC} 3 \mathrm{~b}$, and their respective receptors. Our results suggest that these interactions may be deficient in the milieu of the pseudomonas-infected lung in CF and that both pseudomonas and host proteases may contribute to initiating a vicious cycle in which neutrophils coming into the infected site actually impair phagocytosis rather than eradicating the source of the infection. Thus, the decreased CR1 expression we have documented in this study, although not directly related to the basic defect in CF, may contribute to a local host defense defect which prevents these patients from eradicating pseudomonas from their lungs. This host defense defect and the vicious cycle of infection and inflammation it promotes eventually become the major causes of morbidity and mortality in this genetic disease.

\section{Acknowledgments}

The authors wish to thank Drs. C. Doershuk, G. Legris, A. J. Newman, and R. C. Stern for allowing us to study their patients and Dr. Stern for helpful discussions. This work would not have been possible without the expert assistance of Ms. K. C. Blair and Ms. E. Wetzler.

Supported by a grant from the Rainbow Chapter of the Cystic Fibrosis Foundation and by grants AI-22687 and DK-27651 from the National Institutes of Health. Dr. Berger is a Research Scholar of the Cystic Fibrosis Foundation.

\section{References}

1. Kay, A. B., J. Glass, and D. McG. Salter. 1979. Leucoattractants enhance complement receptors on human phagocytic cells. Clin. Exp. Immunol. 38:294-299.

2. Fearon, D. T., and L. A. Collins. 1983. Increased expression of $\mathrm{C} 3 \mathrm{~b}$ receptors on polymorphonuclear leukocytes induced by chemotactic factors and by purification procedures. J. Immunol. 130:370375.

3. Berger, M., J. O'Shea, A. S. Cross, T. M. Folks, T. L. Chused, E. J. Brown, and M. M. Frank. 1984. Human neutrophils increase expression of $\mathrm{C} 3 \mathrm{bi}$ as well as $\mathrm{C} 3 \mathrm{~b}$ receptors upon activation. J. Clin. Invest. 74:1566-1571.

4. O’Shea, J., E. J. Brown, B. Seligman, J. A. Metcalf, M. M. Frank, and J. I. Gallin. 1985. Evidence for distinct intracellular pools of receptors for $\mathrm{C} 3 \mathrm{~b}$ and $\mathrm{C} 3 \mathrm{bi}$ in human neutrophils. J. Immunol. 134:2580-2587.

5. Todd, R. F. III, M. A. Arnaout, R. E. Rosin, C. A. Crowley, W. A. Peters, and B. M. Babior. 1984. Subcellular localization of the large subunit of Mol, a surface glycoprotein associated with neutrophil adhesion. J. Clin. Invest. 74:1280-1290.

6. Anderson, D. C., F. C. Schmsalstieg, M. J. Finegold, B. J. Hughes, R. Rothlein, L. J. Miller, S. Kohl, M. F. Tosi, R. L. Jacobs, T. C. Waldrop, A. S. Goldman, W. T. Shearer, and T. A. Springer. 
1985. The severe and moderate phenotypes of heritable Mac-1, LFA-1, p 150,95 deficiency: their qualitative definition and relation to leukocyte dysfunction and clinical features. J. Infect. Dis. 152:668-689.

7. Lee, J., R. M. Hakim, and D. T. Fearon. 1984. Increased expression of the $\mathrm{C} 3 \mathrm{~b}$ receptor by neutrophils and complement activation during hemodialysis. Clin. Exp. Immunol. 56:205-214.

8. Arnaout, M. A., R. H. Hakim, R. F. Todd, N. Dana, and H. R. Colten. 1985. Increased expression of an adhesion-promoting surface glycoprotein in the granulocytopenia of hemodialysis. N. Engl. J. Med. 312:457-462.

9. Moore, F. D. Jr., C. Davis, M. Rodrick, J. A. Mannick, and D. T. Fearon. 1986. Neutrophil activation in thermal injury as assessed by increased expression of complement receptors. N. Engl. J. Med. 314:948-953.

10. Zimmerli, N., B. Seligman, and J. I. Gallin. 1986. Exudation primes human and guinea pig neutrophils for subsequent responsiveness to the chemotactic peptide N-FMLP and increases complement component C3bi receptor expression. J. Clin. Invest. 77:925-933.

11. Shalit, M., C. Von Allmen, P. C. Atkins, and B. Zweiman. 1987. Increased expression of CR3 on neutrophils in human inflammatory skin reactions. J. Clin. Immunol. 7:456-462.

12. Schwachman, H., and L. L. Kulczycki. 1958. Long-term study of one hundred five patients with cystic fibrosis. Am. Med. Assoc. J. Dis. Child. 96:6-15.

13. Harbeck, R. J., A. A. Hoffman, S. Redecker, T. Biundo, and J. Kurnick. 1982. The isolation and functional activity of polymorphonuclear leukocytes and lymphocytes separated from whole blood on a single Percoll density gradient. Clin. Immunol. Immunopathol. 23:682-690.

14. Lampson, L. A., and R. Levy. 1980. Two populations of Ia-like molecules on a human B-cell line. J. Immunol. 125:293-299.

15. Phillips, J. H., and G. F. Babcock. 1983. NKP-15: A monoclonal antibody reactive against purified human natural killer cells and granulocytes. Immunol. Lett. 6:143-147.

16. Shapiro, H. M. 1988. Practical Flow Cytometry. 2nd ed. Alan R. Liss, Inc., New York. 129-130, 133-134.

17. Bass, D. A., J. W. Parce, L. R. Dechatelet, P. Szejda, M. C. Seeds, and M. Thomas. 1983. Flow cytometric studies of oxidative product formation by neutrophils: a graded response to membrane stimulation. J. Immunol. 130:1910-1917.

18. Craddock, P. R., J. Fehr, A. Dalmasso, K. Brigham, and H. Jacob. 1977. Hemodialysis leukopenia: pulmonary vascular leukostasis resulting from complement activation by dialyzer cellophane membranes. J. Clin. Invest. 59:879-888.

19. Fernandez, H. N., and T. E. Hugli. 1976. Partial characterization of human C5a anaphylotoxin. I. Chemical description of the carbohydrate and polypeptide portions of human C5a. J. Immunol. 117:1688-1694.

20. Wallis, R. S., H. Fugiwara, and J. J. Ellner. 1986. Direct stimulation of monocyte release of IL-I by mycobacterial protein antigens. $J$. Immunol. 136:193-196.

21. Martodam, R. R., J. Baugh, D. Y. Twumasi, and I. E. Liener. 1979. A rapid procedure for large scale purification of elastase and cathepsin G from human sputum. Prep. Biochem. 9:15-31.

22. Obernesser, H. J., G. Döring, and R. Botzenhart. 1981. Extracellular toxins of Pseudomonas aeruginosa. I. Purification and characterization of two exoproteases. Zentralbl. Bakteriol. Parasitenkd. Infektionskr. Hyg. Abt 1 orig. 249:76-88.

23. Knight, M. E., E. Hartman, Z. Hartman, and V. M. Young. 1979. A new method of preparation of pyocyanine and demonstration of an unusual bacterial sensitivity. Anal. Biochem. 95:19-23.

24. Miller, K. M., D. G. Dearborn, and R. U. Sorensen. 1987. In vitro effect of pyocyanine on neutrophil superoxide production. Infect. Immun. 55:559-563.

25. Quie, P. G., J. G. White, B. Holmes, and R. A. Good. 1967. In vitro bactericidal capacity of human polymorphonuclear leukocytes.
Diminished activity in chronic granulomatous disease of childhood. $J$. Clin. Invest. 46:668-679.

26. Dearborn, D. G., R. L. Waller, M. Berger, and J. Wisnieski. 1986. Decreased superoxide response to F-Met-Leu-Phe by neutrophils from patients with cystic fibrosis. Clin. Res. 34:850a. (Abstr.)

27. Muhlradt, P. F., H. Tsai, and P. Conradt. 1986. Effects of pyocyanine, a blue pigment from $P$. aeruginosa. on separate steps of T-cell activation: IL-2 production, IL-2 receptor formation, proliferation and induction of cytolytic activity. Eur. J. Immunol. 16:434-440.

28. Nutman, J., M. Berger, P. A. Chase, D. G. Dearborn, K. M. Miller, R. L. Waller, and R. U. Sorensen. 1987. Studies on the mechanism of T-cell inhibition by Pseudomonas aeruginosa phenazine pigment pyocyanine. J. Immunol. 138:3481-3487.

29. Berger, M., D. L. Birx, E. M. Wetzler, J. J. O’Shea, E. J. Brown, and A. S. Cross. 1985. Calcium requirements for increased complement receptor expression during neutrophil activation. J. Immunol. 135:1342-1348.

30. Lay, W. H., and V. Nussenzweig. 1968. Receptors for complement on leukocytes. J. Exp. Med. 128:991-1009.

31. Berger, M., T. A. Gaither, and M. M. Frank. 1983. Complement receptors. Clin. Immunol. Rev. 1:471-545.

32. Arnaout, M. A., J. Melamed, B. F. Tack, and H. R. Colten. 1981. Characterization of the human complement $\mathrm{C} 3 \mathrm{~b}$ receptor with a fluid phase C3b dimer. J. Immunol. 127:1348-1354.

33. Berger, M., and A. S. Cross. 1984. Lymphoblastoid cell supernatants increase expression of $\mathrm{C} 3 \mathrm{~b}$ receptors on human polymorphonuclear leukocytes: direct binding studies with ${ }^{125} \mathrm{I}-\mathrm{C} 3 \mathrm{~b}$. Immunology 53:431-440.

34. Gordon, D. L., G. M. Johnson, and M. K. Hostetler. 1987. Characteristics of iC3b binding to human polymorphonuclear leukocytes. Immunology. 60:553-558.

35. Miller, L. J., D. F. Bainton, N. Borregard, and T. A. Springer. 1987. Stimulated mobilization of monocyte Mac-1 and p150,95 adhesion proteins from an intracellular vesicular compartment to the cell surface. J. Clin. Invest. 80:535-544.

36. Myones, B. L., J. G. Dalzell, N. Hogg, and G. D. Ross. 1987. CR4 is p150,95 (CD11c), the third member of the LFA-1/CR3 (CD11a/CD11b) glycoprotein family (CD18). Complement. 4:199. (Abstr.)

37. Freyer, D. R., M. L. Morganroth, C. E. Rogers, M. A. Arnaout, and R. F. Todd III. 1988. Modulation of surface CD11/CD18 glycoproteins by human mononuclear phagocytes. Clin. Immunol. Immunopathol. 46:272-283.

38. Turner, J. R., A. M. Tartakoff, and M. Berger. 1988. Intracellular degradation of the complement $\mathrm{C} 3 \mathrm{~b} / \mathrm{C} 4 \mathrm{~b}$ receptor in the absence of ligand. J. Biol. Chem. 263:4914-4920.

39. Ripoche, J., and R. B. Sim. 1986. Loss of complement receptor type 1 on aging of erythrocytes. Studies of proteolytic release of the receptor. Biochem. J. 235:815-821.

40. Suter, S., U. B. Schaad, L. Roux, U. E. Nydegger, and F. A. Waldvogel. 1984. Granulocyte neutral proteases and pseudomonas elastase as possible causes of airway damage in patients with cystic fibrosis. J. Infect. Dis. 149:523-531.

41. Jackson, A. H., S. L. Hill, S. C. Afford, and R. A. Stockley. 1984. Sputum sol-phase proteases and elastase activity in patients with cystic fibrosis. Eur. J. Respir. Dis. 65:114-124.

42. Goldstein, W., and G. Döring. 1986. Lysosomal enzymes from polymorphonuclear leukocytes and proteinase inhibitors in patients with cystic fibrosis. Am. Rev. Respir. Dis. 134:49-56.

43. Fick, R. B., Jr., G. P. Nagel, S. U. Squier, R. E. Wood, J. B. L. Gee, and H. Y. Reynolds. 1984. Proteins of the cystic fibrosis respiratory tract. Fragmented IgG opsonic antibody causing defective opsonophagocytosis. J. Clin. Invest. 74:236-248.

44. Bruce, M. C., L. Poncz, J. D. Klinger, R. C. Stern, J. Tomashefski, and D. G. Dearborn. 1985. Biochemical and pathological evidence for proteolytic destruction of lung connective tissue in the cystic fibrosis patient. Am. Rev. Respir. Dis. 132:529-535. 
45. Döring, G., W. Goldstein, K. Botzenhart, A. Kharazmi, P. O. Schiotz, N. Hoiby, and M. Dasgupta. 1986. Elastase from polymorphonuclear leukocytes: a regulatory enzyme in immune complex disease. Clin. Exp. Immunol. 64:597-605.

46. Nishino, N., and J. C. Powers. 1980. Pseudomonas aeruginosa elastase. Development of a new substrate, inhibitors, and an affinity ligand. J. Biol. Chem. 255:3482-3486.

47. Barrett, A. J. 1981. Leukocyte elastase. Methods Enzymol. 80:581-588.

48. Mandl, I., S. Keller, and B. Cohen. 1962. Microbial elastases. A comparative study. Proc. Soc. Exp. Biol. Med. 109:923-925.

49. Banda, M. J., and Z. Werb. 1981. Mouse macrophage elastase: purification and characterization as a metalloproteinase. Biochem. $J$. 589:685-687.

50. Tosi, M., and M. Berger. 1988. Functional differences between the $40 \mathrm{kDa}$ and 50 to $70 \mathrm{kDa}$ IgG Fc receptors on human neutrophils revealed by elastase treatment and antireceptor antibodies. $\mathrm{J}$. Immunol. 141:2097-2103.

51. Fearon, D. T. 1980. Identification of the membrane glycopro- tein that is the $\mathrm{C} 3 \mathrm{~b}$ receptor of the human erythrocyte, polymorphonuclear leukocyte, B-lymphocyte and monocyte. J. Exp. Med. 152:20-30.

52. Biggar, W. D., B. Holmes, and R. A. Good. 1971. Opsonic defect in patients with cystic fibrosis of the pancreas. Proc. Natl. Acad. Sci. USA. 68:1716-1719.

53. Thomassen, M. J., B. Boxerbaum, C. A. Demko, P. J. Kuchenbrod, D. G. Dearborn, and R. E. Wood. 1979. Inhibitory effect of cystic fibrosis serum on pseudomonas phagocytosis by rabbit and human alveolar macrophages. Pediatr. Res. 13:1085-1088.

54. Fick, R. B. Jr., G. P. Naegel, R. A. Matthay, and H. Y. Reynolds. 1981. Cystic fibrosis pseudomonas opsonins-inhibitory nature in an in vitro phagocytic assay. J. Clin. Invest. 68:899-914.

55. Ehlenberger, A. G., and V. Nussenzweig. 1977. The role of membrane receptors for $\mathrm{C} 3 \mathrm{~b}$ and $\mathrm{C} 3 \mathrm{~d}$ in phagocytosis. J. Exp. Med. 145:357-373.

56. Murphey, S. A., R. K. Root, and A. D. Schreiber. 1970. The role of antibody and complement in phagocytosis by rabbit alveolar macrophages. J. Infect. Dis. 140:896-903. 